\title{
ENVIRONMENTAL INFORMATION DISCLOSURE TERHADAP FINANCIAL PERFORMANCE DENGAN NILAI PERUSAHAAN SEBAGAI PEMODERASI: PENDEKATAN GAYA PENGUNGKAPAN
}

\author{
MIFTHAKUL JANAH \\ SUSI HANDAYANI \\ Jurusan Akuntansi, Fakultas Ekonomi, Universitas Negeri Surabaya, Jl. Ketintang No. 2, Ketintang, Kec. \\ Gayungan, Kota Surabaya, Indonesia \\ mifthakuljanah16080694052@mhs.unesa.ac.id
}

\begin{abstract}
Companies with a high level of sensitivity to environmental problems will disclose social responsibility reports and sustainability reports as a form of awareness. There is no environmental disclosure standard, causing disclosure to be voluntary, so this study divides the two types of disclosure styles (substantive and symbolic styles). This study aims to determine the effect of EID on financial performance with firm value as a moderating variable with a two-style disclosure approach. The sample in this study was high profile companies listed on the Indonesia Stock Exchange 2017-2018 with 400 samples total divided into two types' disclosures through a purposive sampling technique. Data analysis techniques used multiple linear regression and Moderated Regression Analysis through SPSS 25. The results showed that both the subtantive and symbolic EID styles had a positive effect on financial performance, because the more total EID subtantical and symbolic styles, the more financial performance improved. Then the company's value can moderate the effect of EID on the financial performance of a substantive style company, while the effect of EID on the financial performance of a symbolic style company cannot be moderated by the value of the company, because the substantive style can increase investor confidence through quantitative and actual information disclosed, while the symbolic style is impressed greenwashing in its disclosure so that it cannot give investors confidence.
\end{abstract}

Keywords: Environmental information disclosure, financial performance, firm value, subtantive style, simbolic style

Abstrak: Perusahaan dengan tingkat sensitivitas tinggi terhadap masalah lingkungan akan mengungkapankan laporan tanggung jawab sosial maupun laporan keberlanjutan sebagai bentuk kesadarannya. Standar pengungkapan lingkungan yang belum ada, menyebabkan pengungkapan bersifat sukarela, sehingga penelitian ini membagi dua jenis gaya pengungkapan (gaya subtantif dan simbolik). Penelitian ini bertujuan mengetahui pengaruh EID terhadap kinerja keuangan dengan nilai perusahaan sebagai variabel moderasi dengan pendekatan dua gaya pengungkapan. Sampel dalam penelitian ini adalah perusahaan high profile yang terdaftar di Bursa Efek Indonesia 2017-2018 dengan total sampel 400 terbagi menjadi dua jenis pengungkapan melalui teknik purposive sampling. Teknik analisis data menggunakan regresi linier berganda dan Moderated Regression Analysis melalui SPSS 25. Hasil penelitian menunjukkan EID gaya subtantif maupun simbolik berpengaruh positif terhadap kinerja keuangan, karena semakin banyak total EID gaya subtantif maupun simbolik maka semakin meningkatkan kinerja keuangan. Kemudian nilai perusahaan dapat memoderasi pengaruh EID terhadap kinerja keuangan perusahaan gaya subtantif, sedangkan pengaruh EID terhadap kinerja keuangan perusahaan gaya simbolik tidak dapat dimoderasi oleh nilai perusahaan, karena gaya subtantif dapat meningkatkan kepercayaan para investor melalui 
informasi kuantitatif dan aktual yang diungkapkan, sedangkan gaya simbolik terkesan greenwashing dalam pengungkapannya sehingga tidak bisa memberi kepercayaan bagi investor.

Kata kunci: Pengungkapan informasi lingkungan, kinerja perusahaan, nilai perusahaan, gaya subtantif, gaya simbolik

\section{PENDAHULUAN}

Indonesia merupakan negara berkembang yang terus memacu pertumbuhan ekonominya yang dapat dilihat melalui Pendapatan Domestik Bruto (PDB) setiap tahunnya. Pendapatan Domestik Bruto (PDB) yang didukung peningkatan jumlah penduduk dan perkembangan IPTEK berdampak pada peningkatan perubahan industri di Indonesia. Gaya hidup dan pola konsumsi masyarakat yang beragam menjadi faktor beragamnya industri yang tumbuh di Indonesia. Hasil aktivitas industri yang meningkat berdampak pada meningkatnya pengelolaan dan penanganan limbah hasil aktivitas industri tersebut. Selain total limbah yang dihasilkan dari aktivitas industri, komposisi material kandungan limbah juga semakin sulit diurai secara alami, sehingga menyebabkan pencemaran lingkungan yang berdampak pada kesehatan manusia. Berdasarkan data Badan Pusat Statistik (2018) sumber limbah yang dihasilkan dari aktivitas beberapa industri diantaranya adalah industri pertambangan, energi dan mineral; industri infrastruktur dan jasa; agroindustri; dan industri manufaktur.

Undang-Undang 32 Tahun 2009 tentang Perlindungan Pengelolaan Lingkungan Hidup telah menetapkan bahwa kewajiban mengelola limbah B3 bagi perusahaan penghasil limbah B3 dari aktivitas usahanya. Hal tersebut bertujuan untuk mengurangi atau mencegah risiko akibat dampak buruk dari limbah B3 terhadap lingkungan hidup berupa pencemaran atau degradasi lingkungan hidup. Kesadaran beberapa industri dalam mengelola limbah menunjukkan kepatuhan dan keterbukaannya terhadap peraturan tentang pengelolaan limbah industri dari aktivitas operasinya. Industri tersebut menunjukkan tingkat sensitivitas yang tinggi terhadap masalah lingkungan atau disebut dengan industri high profile (David and Milne, 1996). Perusahaan yang termasuk kategori perusahaan high profile umumnya merupakan perusahaan yang mendapat perhatian lebih dari stakeholder, karena kegiatan operasionalnya memiliki potensi berhubungan dengan kepentingan masyarakat luas.

Kegiatan operasi perusahaan tidak hanya berfokus untuk memaksimalkan keuntungan untuk tujuan jangka panjang para pemegang saham dalam mencapai kinerja ekonomi perusahaan, tanpa mempertimbangkan dan memperhatikan dampak yang timbul dari kegiatan operasinya dari sisi lingkungan dan sosial (Daat dan Pangayow, 2019). Perusahaan perlu menyeimbangkan dan memperhatikan aspek lingkungan dan sosial melalui kegiatan operasi secara berkelanjutan (going concern) dengan memperhatikan konsep 3P (profit, people, planet), ketiga hal tersebut harus saling berkesinambungan. Bentuk kesadaran masyarakat sehubungan dengan masalah lingkungan maupun sosial diungkapkan dalam laporan pengungkapan lingkungan dan tanggung sosial (CSR) maupun sustainbility report yang menjadi sebuah tekanan pada perusahaan untuk mengungkapkan kegiatan mereka secara sukarela maupun wajib. Namun masih belum ada peraturan dari pemerintah tentang standar baku pengungkapan informasi lingkungan, sehingga pengungkapan tersebut menjadi bervariasi dengan bentuk format, isi dan luasnya pengungkapan masih bersifat sukarela sesuai kebijakan perusahaan. 
Environmental Information Disclosure (EID) merupakan bagian dari pengungkapan CSR (Coorporate Social Responbility) sehubungan dengan tanggungjawab perusahaan terhadap sosial dan lingkungan meliputi dimensi ekonomi, sosial dan lingkungan. Environmental Information Disclosure (EID) berisi tentang aktivitas pengelolaan lingkungan dan pengungkapan biaya lingkungan serta informasi kuantitatif maupun kualitatif di dalam laporan tahunan. Beberapa hasil penelitian tentang Environmental Information Disclosure (EID) menunjukkan pengaruh positif antara Environmental Information Disclosure (EID) dan kinerja keuangan perusahaan (Plumlee et al. 2015, Montabon et al. 2007, Nor et al. 2016). Penelitian lain menunjukkan pengaruh negatif (Chen, et al. 2015, Jones et al. 2007).

Berdasarkan praktik Environmental Information Disclosure (EID) masih bersifat sukarela. Menurut Melloni et al. (2017), AlTuwaijri et al. (2004), serta Davies et al. (2007) pengungkapan dilakukan secara selektif dalam memaksimalkan kepentingan perusahaan. Pengungkapan adalah hasil keseimbangan dari suatu proses seleksi dan pengungkapan tersebut meningkatkan prediksi kinerja keuangan. Terdapat dua pendekatan pengungkapan informasi lingkungan yang dapat dilakukan oleh perusahaan untuk mendapatkan legitimasi diantaranya pendekatan substantif dan simbolik (Nasution dan Adhariani, 2016). Pendekatan substantif merupakan perubahan tindakan perusahaan secara konkret bertujuan untuk menyesuaikan strategi organisasi dengan norma sosial yang ada berlaku di masyarakat. Sedangkan pendekatan simbolis merupakan praktik bisnis dilakukan suatu perusahaan dalam memengaruhi persepsi pemangku kepentingan secara positif tanpa benar-benar melakukan perubahan nyata untuk mendapatkan citra perusahaan. Menurut Yin et al. (2019) perusahaan yang mengungkapkan informasi lingkungan mereka dengan gaya substantif menekankan data kuantitatif dalam laporan informasinya. Pendekatan substantif tersebut dapat membantu perusahaan untuk memasuki pasar tertentu, mendapatkan subsidi pemerintah, menghindari hukuman sehubungan dengan lingkungan, sehingga berpengaruh pada peningkatan profitabilitas perusahaan (Ambec and Lanoie, 2008, Berrone et al. 2013, Ghisetti and Rennings, 2014, Ma, et al. 2017, Liu et al. 2017, Wang et al. 2018). Berdasarkan pendekatan gaya simbolis, indeks EID berpengaruh positif pada profitabilitas (financial performance) perusahaan. Perusahaan yang mengungkapkan informasi lingkungan mereka dalam gaya simbolis fokus pada strategi lingkungan, tujuan lingkungan, dan langkahlangkah perlindungan lingkungan dengan menggunakan narasi bahasa (Yin et al. 2019).

Kemampuan perusahaan untuk menghasilkan laba tentunya akan memberikan manfaat bagi pihak eksternal, salah satunya pemegang saham sebagai pihak yang berkepentingan di dalam perusahaan untuk meningkatkan nilai perusahaan tersebut dengan melihat daya tarik investor. Environmental Information Disclosure (EID) termasuk pelaporan berkelanjutan yang terdapat dalam pengungkapan CSR. Berdasarkan penelitian Wijaya dan Pancawati (2019) menyatakan bahwa pengungkapan CSR memiliki pengaruh positif terhadap nilai perusahaan. Penelitian tersebut bertolak belakang dengan penelitian Sawitri dan Setiawan (2017) yang menyatakan bahwa pengungkapan sustainability report yang berisi ekonomi, lingkungan dan sosial tidak berpengaruh terhadap nilai perusahaan. Keterbukaan pengungkapan lingkungan yang tidak disadari dapat meningkatkan nilai perusahaan asalkan mereka dianggap dapat dipercaya oleh investor dan menyampaikan informasi tambahan tentang lingkungan perusahaan (Clarkson et al. 2013). Perusahaan yang melakukan aktivitas pengelolaan lingkungan membawa peningkatan terhadap nilai perusahaan (Mardiana dan Wuryani, 2019).

Berdasarkan perbedaan hasil penelitian tersebut, peneliti ingin melakukan penelitian 
kembali tentang pengaruh Environmental Information Disclosure (EID) terhadap financial performance dengan nilai perusahaan sebagai variabel moderasi berdasarkan pendekatan gaya pengungkapan informasi lingkungan perusahaan, yang kecenderungan pengungkapan informasi lingkungan perusahaan di Indonesia masih bersifat sukarela.

\section{Teori Legitimasi}

Teori yang menyatakan bahwa suatu perusahaan yang dapat bertahan dan berkelanjutan apabila perusahaan tersebut telah menjalankan kegiatan operasi yang sesuai dengan sistem nilai yang berlaku di masyarakat (Suryati dkk. 2019). Perusahaan harus terus memperhatikan aspek sosial maupun lingkungan di sekitarnya, sehingga melalui kepedulian tersebut keberadaan perusahaan dapat diterima di masyarakat agar keberlanjutan hidup perusahaan tetap bertahan.

\section{Teori Stakeholder}

Teori yang mengasumsikan bahwa adanya perusahaan ditentukan oleh para pemangku kepentingannya baik internal maupun eksternal, yang dapat mempengaruhi atau dipengaruhi oleh perusahaan langsung maupun tidak langsung (Freeman and Dmytriyev, 2017). Fungsi internal sehubungan dengan biaya konservasi lingkungan yang efektif dan efisien sesuai dengan pengambilan keputusan. Fungsi eksternal mempengaruhi pengambilan keputusan stakeholder dalam menganalisa data akuntansi lingkungan, kegiatan lingkungan serta apa yang dihasilkan dan pencegahannya, serta isu-isu pertanggungjawaban sosial lainnya.

\section{Teori Signaling}

Teori yang menjelaskan tentang pemberian sinyal kepada pengguna laporan keuangan melalui langkah maupun cara yang seharusnya dilakukan oleh perusahaan. Sinyal tersebut berupa sinyal informasi untuk merealisasikan keinginan pemilik atas apa yang sudah dilakukan oleh manajemen (Suryati et al. 2019). Sinyal positif meningkatkan nilai dan kinerja perusahaan, sedangkan sinyal negatif akan mempengaruhi harga saham dan permintaan produk berkurang. Perusahaan berkualitas tinggi biasanya lebih termotivasi untuk mengirim sinyal berkualitas tinggi.

\section{Environmental Information Disclosure}

Environmental Information Disclosure (EID) merupakan pengungkapan informasi sehubungan dengan lingkungan yang tercantum dalam laporan tahunan maupun sustainbility report perusahaan. Pengungkapan lingkungan hidup tersebut membantu masyarakat dalam mengawasi aktivitas-aktivitas yang dilakukan oleh perusahaan sehubungan dengan kegiatan usahanya dalam rangka memenuhi tanggung jawab sosialnya (Sari dkk. 2019).

\section{Gaya Pengungkapan Informasi Lingkungan \\ Berdasarkan penelitian Nasution dan} Adhariani, (2016) legitimasi perusahaan dapat dilakukan melalui dua pendekatan yaitu menggunakan pendekatan substantif dan pendekatan simbolik. Perusahaan yang mengungkapkan informasi lingkungan mereka dengan gaya substantif menekankan data kuantitatif dalam laporan informasi yang bersifat aktual. Sedangkan, pendekatan simbolis berupa praktik bisnis yang dilakukan oleh perusahaan dalam memengaruhi persepsi pemangku kepentingan secara positif tanpa benar-benar melakukan perubahan atau tindakan nyata. Identifikasi kedua jenis gaya pengungkapan subtantif maupun simbolik, dilakukan dengan menjumlahkan skor item informasi obyektif perusahaan dan skor item informasi subjektif masing-masing industri, kemudian menghitung selisihnya. Jika hasilnya $>0$ gaya pengungkapannya cenderung substantif. Sebaliknya, jika hasilnya $<0$, gaya 
pengungkapannya cenderung simbolik (Yin et al. 2019).

\section{Kinerja Keuangan \\ Kinerja keuangan (financial}

Performance) merupakan gambaran tentang baik buruknya keadaan keuangan perusahaan melalui alat-alat analisis keuangan, sehingga dapat mencerminkan prestasi kerja yang dicapai perusahaan selama periode tertentu (Fahmi, 2011:2).

\section{Nilai Perusahaan}

Nilai perusahaan merupakan tingkat keberhasilan perusahaan berdasarkan persepsi pemegang saham berkaitan dengan harga saham (Mardiana \& Wuryani, 2019). Harga saham yang semakin tinggi memberi pengaruh peningkatan pada nilai perusahaan, sehingga kepercayaan pasar juga semakin meningkat yang berdampak pada kinerja perusahaan dan prospek perusahaan di masa depan.

\section{Pengaruh Environmental Information Disclosure terhadap financial performance untuk pengungkapan gaya subtantif}

Perusahaan yang mengungkapkan informasi lingkungan mereka dengan gaya substantif menekankan data kuantitatif dalam laporannya. Pendekatan gaya substantif dapat membantu perusahaan untuk memasuki pasar tertentu, mendapatkan subsidi pemerintah, menghindari hukuman sehubungan dengan lingkungan dan litigasi, sehingga berpengaruh pada peningkatan profitabilitas perusahaan (Ambec and Lanoie, 2008; Berrone et al. 2013; Ghisetti and Rennings, 2014; Ma, et al. 2017; Liu et al. 2017; Wang et al. 2018). Hasil penelitian Yin et al. (2019) menunjukkan bahwa pengungkapan Environmental Information Disclosure (EID) dengan gaya substantif hasilnya positif terhadap profitabilitas. Sehingga hipotesis dalam penelitian ini adalah sebagai berikut:

$\mathrm{H}_{1}=$ Environmental Information Disclosure (EID) berpengaruh positif terhadap financial performance untuk pengungkapan gaya subtantif

\section{Pengaruh Environmental Information Disclosure terhadap Financial Performance untuk pengungkapan gaya simbolik \\ Perusahaan yang mengungkapkan} informasi lingkungan mereka dalam gaya simbolis fokus pada strategi, tujuan, dan langkah-langkah perlindungan lingkungan dengan menggunakan narasi bahasa, sementara informasi kuantitatif sedikit. Semakin tekstual informasi maka semakin menarik publik (Cormier \& Magnan, 2013). Oleh karena itu, perusahaan juga dapat mencari keuntungan yang baik di pasar melalui publisitas lingkungan. Hasil penelitian Yin et al. (2019) menunjukkan bahwa pengungkapan Environmental Information Disclosure (EID) dengan gaya simbolik hasilnya positif terhadap profitabilitas. Sehingga hipotesis dalam penelitian ini adalah sebagai berikut:

$\mathrm{H}_{2}=$ Environmental Information Disclosure berpengaruh positif terhadap financial performance untuk pengungkapan gaya simbolik

\section{Nilai perusahaan dapat memoderasi pengaruh Environmental Information Disclosure terhadap financial performance untuk pengungkapan gaya subtantif}

Hubungan pengungkapan lingkungan dan nilai perusahaan, keduanya sering dikaitkan dengan isu-isu atau peristiwa lingkungan tertentu sehubungan dengan harga atau perubahan harga saham (Plumlee et al. 2015). Perusahaan yang melakukan pengungkapan substantif memiliki praktik lingkungan secara aktual, memberikan citra yang baik kepada para investor yang akan meningkatkan nilai tambah bagi perusahaan. Komitmen lingkungan yang baik dapat meningkatkan nilai perusahaan bertujuan untuk pemangku kepentingan melalui transparansi pengungkapan informasi lingkungannya yang terdapat dalam laporan keberlanjutan (Pratama dkk. 2020). Sehingga 
hipotesis dalam penelitian ini adalah sebagai berikut:

$\mathrm{H}_{3}=$ Nilai perusahaan dapat memoderasi pengaruh Environmental Information Disclosure (EID) terhadap financial performance untuk pengungkapan gaya subtantif

\section{Nilai perusahaan dapat memoderasi pengaruh Environmental Information Disclosure terhadap financial performance untuk pengungkapan gaya simbolik}

Perusahaan yang mengungkapkan gaya simbolik lebih banyak menggambarkan perilaku dan visi perusahaan dalam laporan informasinya. Gaya simbolik dapat membantu perusahaan untuk membangun citra perusahaan dengan bertanggung jawab terhadap lingkungan, mencari legitimasi sosial, dan melobi pemangku kepentingan di pasar modal, pasar produk, dan bidang lainnya (Yin et al. 2019). Pengungkapan simbolik dapat menutupi kelonggaran inisiatif lingkungan perusahaan, menciptakan citra perusahaan sehingga berdampak pada profitabilitas perusahaan (Ramus and Montiel, 2005, Du 2015). Sehingga hipotesis dalam penelitian ini adalah:

$\mathrm{H}_{4}=$ Nilai perusahaan dapat memoderasi pengaruh Environmental Information Disclosure terhadap financial performance untuk pengungkapan gaya simbolik.

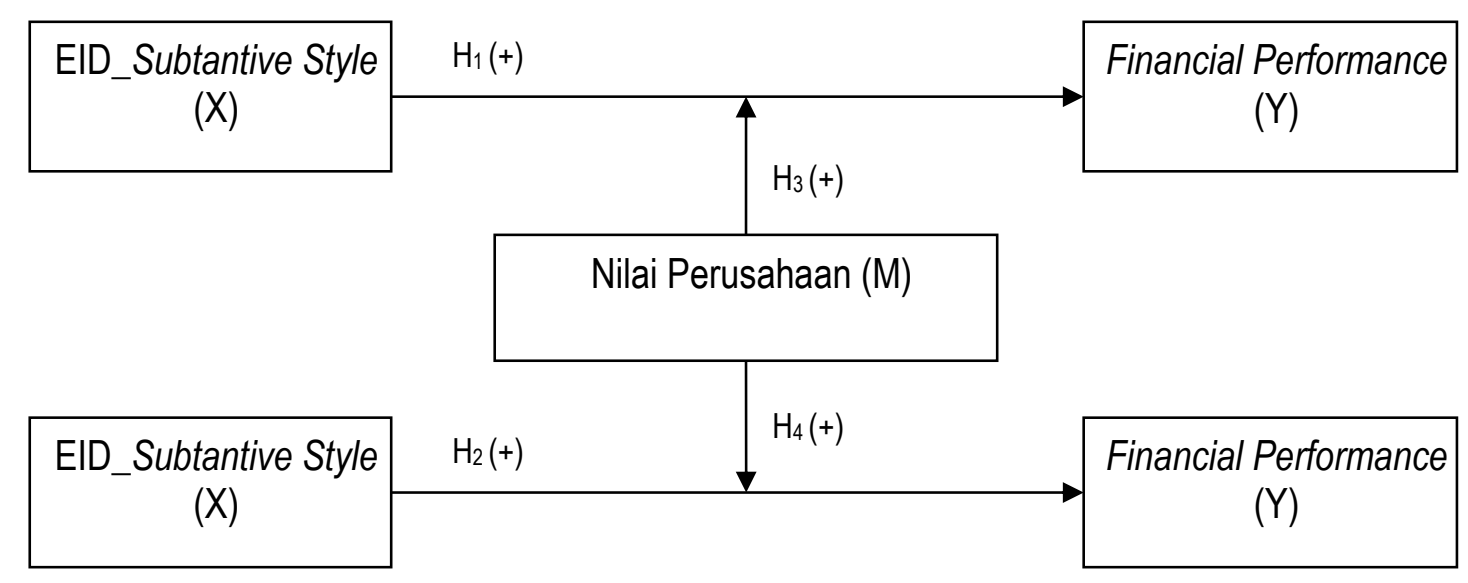

\section{Gambar 1 Model Penelitian}

\section{METODE PENELITIAN}

Jenis penelitian kuantitatif digunakan dalam penelitian ini dan bersumber dari laporan keuangan maupun laporan keberlanjutan yang terdaftar di BEI maupun website resmi perusahaan periode 2017-2018. Penelitian ini mengambil sampel perusahaan high profile yang terdaftar di BEI berdasarkan klasifikasi Jakarta Stock Industrial Classification (JASICA) yang meliputi sektor pertama (sektor pertanian dan sektor pertambangan) dan sektor kedua (sektor industri dasar \& kimia, sektor aneka industri, dan sektor barang konsumsi. Teknik pengambilan sampel menggunakan purposive sampling. Jumlah perusahaan yang memenuhi kriteria sampel sebanyak 200 perusahaan kemudian dibagi menjadi dua pendekatan gaya pengungkapan. Sebanyak 200 perusahaan, selama periode 2017-2018 menghasilkan total sampel keseluruhan sebanyak 400.

Pengukuran kinerja keuangan (financial performance) menggunakan Return On Equity (ROE) merupakan rasio keuntungan atas hak modal sendiri dan sering dipakai oleh para investor dalam pembelian saham suatu perusahaan karena modal sendiri menjadi 
bagian pemilik (Rahardjo, 2007:121). Berikut ini cara menghitung ROE:

$$
\text { Return On Equity }=\frac{\text { Earning after tax }}{\text { Total equity }}
$$

\section{Environmental Information Disclosure} (EID) memuat informasi objektif dan informasi subjektif. Informasi objektif dikelompokkan menjadi empat item yang meliputi struktur tata kelola perusahaan, kredibilitas perusahaan, indikator kinerja lingkungan dan pendanaan lingkungan. Sedangkan dalam informasi subjektif dikelompokkan menjadi tiga item yang meliputi visi dan strategi, profil lingkungan dan tindakan inisiatif lingkungan. Indeks EID merupakan proksi yang digunakan untuk menghitung total Environmental Information Disclosure (EID). Berikut cara menghitung indeks EID:

$$
\text { EIDI }=\text { Total Objektif }+ \text { Total Subjektif }
$$

Nilai perusahaan merupakan gambaran atas besarnya penilaian pemegang saham terhadap kinerja perusahaan secara keseluruhan. Rasio Tobin's $Q$ merupakan proksi nilai perusahaan. Tobin's $Q$ menghasilkan nilai $>1$ menunjukkan bahwa nilai pasar (market value) lebih tinggi dibandingkan nilai aset perusahaan, sehingga investasi dikatakan lebih menatik (Mardiana and Wuryani 2019). Berikut cara menghitung Tobin's Q:

$$
\text { Tobins }^{\prime} Q=\frac{\text { Market Value }+ \text { Liabilities }}{\text { Asset Total }}
$$

Ukuran perusahaan (Size) merupakan skala yang menentukan besar atau kecilnya perusahaan. Berikut cara menghitung ukuran perusahaan:

$$
\text { Size }=\operatorname{Ln}(\text { Total Aset })
$$

Pertumbuhan penjualan (Growth) mencerminkan keberhasilan investasi periode masa lalu dan dapat dijadikan prediksi pertumbuhan masa yang akan datang. Rasio pertumbuhan dalam penelitian ini dapat dilihat dari segi penjualan yang dapat dihitung sebagai berikut:

$$
\text { Growth }=\frac{\text { Penjualan } t-\text { Penjualan } t-1}{\text { Penjualan } t-1}
$$

Leverage merupakan rasio utang atas aset yang menunjukkan seberapa besar perusahaan dibiayai dengan utang, menngunakan rumus debt to asset ratio (DAR) Berikut cara menghitung DAR:

$$
D A R=\frac{\text { Total Utang }}{\text { Total Aset }}
$$

Regresi linier berganda (multiple linier regression analysis) dan MRA (moderated regression analysis) digunakan dalam penelitian ini. Pengaruh antara variabel independen, variabel dependen, variabel kontrol, dan variabel moderating menggunakan regresi linier berganda. Sedangkan, pengaruh variabel moderasi dalam pengaruh antara variabel independen dan variabel dependen menggunakan MRA (moderated regression analysis) melalui program SPSS 25. Sebelum melakukan uji hipotesis diperlukan uji asumsi klasik berupa uji normalitas, multikolerasi, heterokedastisitas, dan autokorelasi. Berikut model persamaan regresi yang digunakan dalam penelitian ini:

\section{Model Persamaan 1}

$$
\mathrm{FP}_{\mathrm{s}}=a+\beta_{1} \mathrm{EID}_{\mathrm{s}}+\beta_{2} \mathrm{SIZE}_{\mathrm{s}}+\beta_{3} \mathrm{GROWTH}_{\mathrm{s}}+
$$
$\beta_{4} L E V_{s}+\beta_{5} Q_{s}+\varepsilon$

\section{Model Persamaan 2}

$F P_{s}=a+\beta_{1} E_{\text {EID }}+\beta_{2}$ SIZE $_{s}+\beta_{3}$ GROWTH $_{s}+$ $\beta_{4} \mathrm{LEV}_{\mathrm{s}}+\beta_{5} \mathrm{Q}_{\mathrm{s}}+\beta_{6} \mathrm{EIDI}_{\mathrm{s}}{ }^{*} \mathrm{Q}_{\mathrm{s}}+\varepsilon$

Ket:

s :Style,1(subtantive style), 0(simbolic style) 
Kriteria pengujian model $1\left(\mathrm{H}_{1}\right.$ dan $\left.\mathrm{H}_{2}\right)$ EID berpengaruh positif terhadap kinerja keuangan (financial performance) apabila $\mathrm{H}_{1}$ $\left(\beta_{1} E_{I} D_{1}>0\right.$ dan sig. $\left.<0,05\right)$ dan $\mathrm{H}_{2}\left(\beta_{1} E_{I} D_{0}>0\right.$ dan sig. $<0,05)$. Pengujian model $2\left(\mathrm{H}_{3}\right.$ dan $\left.\mathrm{H}_{4}\right)$
Nilai perusahaan dapat memoderasi pengaruh EID dengan kinerja keuangan (financial performance) apabila $\mathrm{H}_{3}\left(\beta_{6} \mathrm{EID}_{1}{ }^{*} \mathrm{Q}_{1}>0\right.$ dan sig. $<0,05)$ dan $\mathrm{H}_{4}\left(\beta_{6} \mathrm{EID}_{0}{ }^{*} \mathrm{Q}_{0}>0\right.$ dan sig.< $0,05)$.

\section{HASIL DAN PEMBAHASAN}

Tabel 1 Statistik Deskriptif Pengungkapan Gaya Subtantif

\begin{tabular}{lrrrr}
\hline Keterangan & Min. & Max. & Mean & Std. Deviasi \\
\hline FP & $-3,56$ & 2,55 & 0.11 & 0,48 \\
EID & 9,00 & 67,00 & 29,13 & 16.97 \\
SIZE & 2,71 & 32,20 & 23,40 & 9,35 \\
GROWTH & $-0,79$ & 63,02 & 0,47 & 4,37 \\
LEVERAGE & 0,08 & 2,90 & 0,52 & 0,32 \\
Q & 0,28 & 23,29 & 2,01 & 2,88 \\
\hline
\end{tabular}

Sumber: Data diolah SPSS 25,2020

Berdasarkan identifikasi gaya pengungkapan terdapat 200 perusahaan high profile. Pada Tabel 1 sebanyak 105 perusahaan mengungkapkan informasi lingkungannya menggunakan gaya subtantif melalui pengungkapan CSR yang berisi informasi sosial dan lingkungan sesuai pendekatan subtantif mengikuti pedoman pelaporan dan keterlibatan pemangku kepentingan. Rata-rata kinerja keuangan (ROE) adalah 0,11 yang menunjukkan bahwa rata-rata tiap $100 \%$ dari ekuitas pemegang saham, perusahaan dapat menghasilkan laba bersih sebesar $11 \%$. Nilai maksimum ROE dimiliki oleh PT Central Proteinaprima dan nilai minimum ROE dimiliki oleh PT Bakrie Sumatera Plantation. Rata-rata EID sebesar 29,13 (dalam rentang 9 hingga 67 dan standar deviasi 16,97) menunjukkan bahwa total EID perusahaan gaya subtantif cenderung tinggi. Total Environmental Information Disclosure (EID) perusahaan dengan gaya subtantif yang relatif tinggi beberapa diantaranya PT Eagle High Plantation, PT Aneka Tambang, PT Indocement Tunggal Prakasa, PT Astra
International PT Unilever. Perusahaan tersebut mengungkapkan EID secara rinci dalam sustainbility report. Sedangkan ukuran perusahaan memiliki rata-rata 23,40 menunjukkan bahwa ukuran perusahaan gaya subtantif cukup besar dengan nilai maksimum dimiliki oleh PT Indofood Sukses Makmur dan nilai minimum dimiliki oleh PT Eratex Djaya dan PT Trisula International. Rata-rata pertumbuhan perusahaan gaya subtantif sebesar 0,47 dengan pertumbuhan perusahaan tertinggi dimiliki oleh PT Bumi Resources. Rata-rata leverage sebesar 0,52 dengan nilai maksimum leverage dimiliki oleh PT Tiga Pilar Sejahtera Food dan nilai minimum leverage dimiliki oleh PT Sido Muncul. Ratarata $Q$ sebesar 2,01 (dalam rentang 0,28 hingga 23,29 dan standar deviasi 2,88) menunjukkan bahwa nilai tersebut di atas angka 1 yang mengindikasikan bahwa investasi lebih menarik karena nilai pasar lebih tinggi dibandingkan nilai aset perusahaan, dengan nilai maksimum $Q$ dimiliki oleh PT Unilever Indonesia dan nilai minimum $Q$ dimiliki oleh $\mathrm{PT}$ Sat Nusa Persada. 
Tabel 2 Statistik Deskriptif Pengungkapan Gaya Simbolik

\begin{tabular}{lllrr}
\hline Keterangan & Min. & Max. & Mean & Std. Deviasi \\
\hline FP & $-189,86$ & 0,83 & $-1,01$ & 13,79 \\
EID & 4 & 24 & 13,44 & 4,11 \\
SIZE & 1,95 & 30,95 & 20,88 & 10,51 \\
GROWTH & $-0,88$ & 42,72 & 0,49 & 3,24 \\
LEVERAGE & 0,08 & 5,07 & 0,54 & 0,54 \\
Q & 0,32 & 53,40 & 1,61 & 3,90 \\
\hline
\end{tabular}

Sumber: Data diolah SPSS 25, 2020

Sedangkan pada Tabel 2 dari 200 perusahaan high profile terdapat 95 perusahaan menggunakan pengungkapan dengan pendekatan gaya simbolik, secara umum pengungkapkan lingkungan tergabung menjadi satu dengan laporan tahunannya. Rata-rata kinerja keuangan (ROE) adalah $-1,01$ yang menunjukkan bahwa rata-rata tiap $100 \%$ dari ekuitas pemegang saham, perusahaan dapat menghasilkan laba bersih sebesar $-1,01$. Rata-rata ROE perusahaan gaya simbolik cenderung rendah dengan nilai terendah ROE dimiliki oleh PT Capitalinc Investment. Ratarata EID sebesar 13,44 menunjukkan bahwa total EID perusahaan gaya simbolik cenderung tinggi. Total Environmental Information Disclosure (EID) perusahaan dengan gaya simbolik yang relatif tinggi beberapa diantaranya PT Golden Plantation, PT Golden Energy Mines, PT Citra Turbindo, PT Steel Pipe Industry of Indonesia. Sedangkan ukuran perusahaan memiliki rata-rata 20,88 menunjukkan bahwa ukuran perusahaan gaya simbolik cukup besar dengan nilai maksimum dimiliki oleh PT Charoen Pokphand Indonesia dan nilai minimum dimiliki oleh PT Argo Pantes. Rata-rata pertumbuhan perusahaan gaya simbolik sebesar 0,49 dengan pertumbuhan perusahaan tertinggi dimiliki oleh PT Capitalinc Investment. Rata-rata leverage sebesar 0,54 dengan nilai maksimum leverage dimiliki oleh PT Asia Pacific Fibers dan nilai minimum leverage dimiliki oleh PT Atlas Resources dan PT Tifico Fiber Indonesia. Rata-rata $Q$ sebesar 1,61 (dalam rentang 0,32 hingga 53,40 dan standar deviasi 3,90) menunjukkan bahwa nilai tersebut di atas angka 1 yang mengindikasikan bahwa investasi lebih menarik karena nilai pasar lebih tinggi dibandingkan nilai aset perusahaan, dengan nilai tertinggi $Q$ dimiliki oleh PT Prima Cakrawala Abadi. 
Tabel 3 Uji Hipotesis Model 1 Gaya Subtantif

\begin{tabular}{llll}
\hline \multirow{2}{*}{ Model 1 } & \multicolumn{3}{c}{ Gaya Subtantif (1) } \\
\cline { 2 - 4 } & $\mathbf{B}$ & St.Error & Sig.t \\
\hline Konstanta & 0,009 & 0,042 & 0,841 \\
EID & 0,001 & 0,001 & 0,005 \\
SIZE & $-0,002$ & 0,001 & 0,189 \\
GROWTH & 0,104 & 0,048 & 0,031 \\
LEV & $-0,043$ & 0,034 & 0,204 \\
Q & 0,069 & 0,015 & 0,000 \\
\hline Sig. F & $\mathbf{0 , 0 0 0}$ & & \\
R-Square & $\mathbf{0 , 3 1 4}$ & &
\end{tabular}

Sumber: Data diolah SPSS 25,2020

Hasil analisis model 1 pada tabel 3 dapat diketahui bahwa Environmental Information Disclosure (EID) pendekatan gaya subtantif menunjukkan besarnya nilai signifikansi 0,005 $<0,05$ dan nilai $(\beta)$ positif sebesar 0,001 sehingga $\mathrm{H}_{1}$ diterima. $\mathrm{Hal}$ tersebut menunjukkan bahwa semakin banyak total Environmental Information Disclosure (EID) maka akan meningkatkan kinerja keuangan. Sedangkan ukuran perusahaan dan leverage memiliki nilai signifikansi $>0,05$, yang menunjukkan bahwa ukuran perusahaan dan leverage untuk gaya subtantif tidak berpengaruh terhadap kinerja keuangan. Kemudian pertumbuhan perusahaan dan nilai perusahaan untuk gaya subtantif memiliki nilai signifikansi $<0,05$. Hal ini berarti setiap terjadi kenaikan nilai pertumbuhan perusahaan dan nilai perusahaan akan diikuti kenaikan kinerja keuangan. Pengujian secara simultan (Uji F) semua variabel model 1 untuk perusahaan gaya subtantif berpengaruh terhadap kinerja keuangan, dengan nilai signifikansi $<0,05$. Nilai $R^{2}$ perusahaan gaya subtantif sebesar $31,4 \%$ yang menunjukkan bahwa variasi financial performance dapat dijelaskan oleh variasi kelima variabel independen tersebut dan sisanya $68,6 \%$ tidak dijelaskan oleh sebabsebab lain di dalam model.

Tabel 4 Uji Hipotesis Model 1 Gaya Simbolik

\begin{tabular}{lllc}
\hline \multirow{2}{*}{ Model 1 } & \multicolumn{3}{c}{ Gaya Simbolik (0) } \\
\cline { 2 - 4 } & $\mathbf{B}$ & St.Error & Sig.t \\
\hline Konstanta & $-0,066$ & 0,068 & 0,330 \\
EID & 0,007 & 0,002 & 0,001 \\
SIZE & $-0,001$ & 0,002 & 0,699 \\
GROWTH & 0,100 & 0,044 & 0,024 \\
LEV & $-0,088$ & 0,033 & 0,008 \\
Q & 0,080 & 0,016 & 0,000 \\
\hline Sig. F & $\mathbf{0 , 0 0 0}$ & & \\
R-Square & $\mathbf{0 , 2 5 3}$ & & \\
\hline
\end{tabular}

Sumber: Data diolah SPSS 25,2020 
Sedangkan pada tabel 4 untuk model 1 menunjukkan bahwa Environmental Information Disclosure (EID) untuk pendekatan gaya simbolik menunjukkan besarnya nilai signifikansi $0,001<0,05$ dan nilai $(\beta)$ positif sebesar 0,07 sehingga $\mathrm{H}_{2}$ diterima. Hal tersebut menunjukkan bahwa semakin banyak total Environmental Information Disclosure (EID) maka akan meningkatkan kinerja keuangan. Kemudian leverage untuk gaya simbolik memiliki nilai signifikansi $<0,05$ dan nilai $(\beta)$ negatif yang berarti kenaikan leverage akan diikuti penurunan kinerja keuangan (ROE).
Sedangkan pertumbuhan perusahaan dan nilai perusahaan gaya simbolik memiliki nilai signifikansi $<0,05$. Pengujian secara simultan

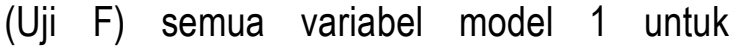
perusahaan gaya simbolik berpengaruh terhadap kinerja keuangan, dengan nilai signifikansi $<0,05$. Nilai $R^{2}$ perusahaan gaya simbolik sebesar $25,3 \%$ menunjukkan bahwa variasi financial performance dapat dijelaskan oleh variasi kelima variabel independen tersebut dan sisanya $74,7 \%$ tidak dijelaskan oleh sebab-sebab lain di dalam model.

\section{Tabel 5 Uji Hipotesis Model 2 Gaya Subtantif}

\begin{tabular}{llll}
\hline \multirow{2}{*}{ Model 2} & \multicolumn{3}{c}{ Gaya Subtantif (1) } \\
\cline { 2 - 4 } & $\mathbf{B}$ & St.Error & Sig.t \\
\hline Konstanta & 0,126 & 0,055 & 0,025 \\
EID & $-0,004$ & 0,002 & 0,034 \\
SIZE & $-0,001$ & 0,001 & 0,431 \\
GROWTH & 0,130 & 0,047 & 0,006 \\
LEV & $-0,027$ & 0,033 & 0,421 \\
Q & $-0,069$ & 0,046 & 0,140 \\
EID* Q & 0,005 & 0,001 & 0,002 \\
\hline Sig. F & $\mathbf{0 , 0 0 0}$ & & \\
R-Square & $\mathbf{0 , 3 6 4}$ & & \\
\hline Sumber: & & & \\
\hline
\end{tabular}

Sumber: Data diolah SPSS 25, 2020

Pada hasil analisis model 2 pada tabel 5 dapat diketahui bahwa Environmental Information Disclosure (EID) memiliki nilai siginifikansi $<0,05$ dan nilai $(\beta)$ negatif artinya EID berpengaruh negatif terhadap kinerja keuangan, hal ini menunjukkan EID gaya subtantif cenderung mengungkapkan data kuantitatif termasuk biaya lingkungan dimana semakin banyaknya biaya yang diungkapkan akan berdampak pada penurunan kinerja keuangan. Pertumbuhan perusahaan untuk perusahaan gaya subtantif memiliki nilai siginifikansi $<0,05$ dan nilai $(\beta)$ positif artinya pertumbuhan perusahaan berpengaruh positif terhadap kinerja keuangan, yang menunjukkan bahwa perusahaan yang memiliki pertumbuhan yang tinggi, diharapkan akan menghasilkan keuntungan di masa depan, sehingga menarik investor untuk menanamkan modalnya tersebut. Kemudian ukuran perusahaan, leverage dan nilai perusahaan memiliki nilai siginifikansi > 0,05 artinya tidak berpengaruh terhadap kinerja keuangan. Sedangkan untuk interaksi antara variabel Environmental Information Disclosure (EID) dan nilai perusahaan untuk pendekatan gaya subtantif memiliki nilai siginifikansi 0,002 $<0,05$ dan nilai $(\beta)$ positif, yang artinya nilai perusahaan dapat memoderasi pengaruh EID dengan kinerja keuangan untuk perusahaan gaya subtantif sehingga $\mathrm{H}_{3}$ diterima. Pengujian secara simultan (Uji F) semua variabel model 2 untuk gaya subtantif berpengaruh terhadap 
kinerja keuangan dengan nilai signifikansi < 0,05 . Nilai $R^{2}$ perusahaan gaya subtantif sebesar $36,4 \%$ menunjukkan bahwa variasi financial performance dijelaskan oleh variasi keenam variabel independen tersebut dan sisanya $63,6 \%$ tidak dijelaskan oleh sebabsebab lain di dalam model.

Tabel 6 Uji Hipotesis Model 2 Gaya Simbolik

\begin{tabular}{lccc}
\hline \multirow{2}{*}{ Model 2 } & \multicolumn{2}{c}{ Gaya Simbolik (0) } & St.Error \\
\cline { 2 - 4 } & $\mathbf{B}$ & 0,085 & Sig.t \\
\hline Konstanta & $-0,085$ & 0,005 & 0,322 \\
EID & 0,009 & 0,002 & 0,073 \\
SIZE & $-0,001$ & 0,044 & 0,687 \\
GROWTH & 0,100 & 0,033 & 0,024 \\
LEV & $-0,089$ & 0,055 & 0,008 \\
Q & 0,099 & 0,004 & 0,076 \\
EID* Q & $-0,001$ & & 0,720 \\
\hline Sig. F & $\mathbf{0 , 0 0 0}$ & & \\
R-Square & $\mathbf{0 , 2 5 4}$ & &
\end{tabular}

Sedangkan pada hasil analisis model 2 pada tabel 6 untuk pendekatan gaya simbolik Environmental Information Disclosure (EID), ukuran perusahaan dan nilai perusahaan memiliki nilai signifikansi $>0,05$, yang berarti tidak berpengaruh terhadap kinerja keuangan. Sedangkan pertumbuhan perusahaan memiliki nilai siginifikansi $<0,05$ dan nilai $(\beta)$ positif, artinya pertumbuhan perusahaan semakin meningkat diiringi dengan peningkatan kinerja keuangannya. Kemudian leverage memiliki nilai siginifikansi $<0,05$ dan nilai $(\beta)$ negatif, artinya semakin besar utang perusahaan tentu akan menurunkan kinerja keuangan perusahaan gaya simbolik. Sedangkan interaksi antara variabel Environmental Information Disclosure (EID) dan nilai perusahaan pendekatan gaya simbolik memiliki nilai siginifikansi sebesar $0,254>0,05$ yang artinya nilai perusahaan tidak dapat memoderasi pengaruh EID dengan kinerja keuangan untuk perusahaan gaya simbolik sehingga $\mathrm{H}_{4}$ ditolak. Pengujian secara simultan (Uji F) semua variabel model 2 untuk gaya simbolik berpengaruh terhadap kinerja keuangan dengan nilai signifikansi $<0,05$. Nilai $\mathrm{R}^{2}$ perusahaan gaya simbolik sebesar $25,4 \%$ menunjukkan bahwa variasi financial performance dijelaskan oleh variasi keenam variabel independen tersebut dan sisanya $74,6 \%$ dijelaskan oleh sebab-sebab lain di dalam model.

\section{Pembahasan}

Hasil pengujian menunjukkan bahwa Environmental Information Disclosure (EID) berpengaruh positif terhadap kinerja keuangan untuk pengungkapan gaya subtantif. Perusahaan dengan pengungkapan subtantif memiliki praktik lingkungan secara aktual yang dapat meningkatkan kinerja perusahaan melalui kinerja keuangannya. Hal tersebut sejalan dengan penelitian Ambec and Lanoie (2008) dan Berrone et al. (2013) bahwa Environmental Information Disclosure (EID) secara subtantif dapat membantu perusahaan dalam memasuki pasar tertentu, mendapatkan subsidi pemerintah, dan menghindari hukuman lingkungan yang akan berdampak terhadap kinerja keuangan perusahaan. Berdasarkan teori stakeholder menyatakan bahwa berdirinya perusahaan ditentukan oleh para pemangku kepentingannya baik internal maupun eksternal. 
Menurut Ikhsan (2009:34) manajer sebagai pihak internal fokus pada sudut pandang informasi akuntansi lingkungan melalui peningkatan nilai perusahaan yang menjadi tolak ukur keberhasilan kinerja perusahaan, sedangkan pihak eksternal yaitu investor dan lembaga keuangan berfokus pada dasar pengambilan keputusan dalam melakukan pengujian informasi secara rinci pada aspek keuangan perusahaan.

Informasi lingkungan secara rinci yang terdapat dalam gaya subtantif tersebut tidak hanya misi perusahaan sehubungan dengan lingkungan, struktur organisasi sehubungan dengan lingkungan, langkah-langkah pengelolaan lingkungan, dll, tetapi juga data kuantitatif yang akurat tentang investasi perlindungan lingkungan, investasi hemat energi, konsumsi energi komprehensif, konsumsi energi per unit output, konsumsi energi logistik, konsumsi air, air limbah, pemanfaatan, emisi gas polutan (SO 2 , NO x ), reklamasi lahan, dll. Informasi-informasi tersebut mendorong perusahaan untuk mengungkapkan secara aktual tindakan operasinya sehubungan dengan aktivitas lingkungan yang menjadi suatu kesadaran bagi perusahaan yang memiliki sensitivitas tinggi terhadap masalah lingkungan. Oleh karena itu, melalui peningkatan kesadaran dalam mengungkapkan informasi lingkungannya maka akan meningkatkan kinerja keuangan perusahaan.

Hasil pengujian menunjukkan bahwa Environmental Information Disclosure (EID) berpengaruh positif terhadap kinerja keuangan untuk pengungkapan gaya simbolik. Perusahaan dengan pengungkapan gaya simbolik lebih banyak menggambarkan perilaku dan visi perusahaan. Praktik bisnis yang dilakukan oleh perusahaan dengan pendekatan gaya simbolik dilakukan untuk mempengaruhi persepsi pemangku kepentingan secara positif, tanpa melakukan perubahan atau tindakan nyatasecara nyata, bertujuan untuk mencari keuntungan dalam menarik minat investor. Hasil penelitian ini didukung oleh Ramus and Montiel (2005) dan Du (2015) bahwa pengungkapan simbolik dapat menutupi kelonggaran inisiatif lingkungan perusahaan, menciptakan citra perusahaan yang dapat membawa sumber daya ke perusahaan sehingga pada akhirnya berdampak pada profitabilitas perusahaan.

Berdasarkan teori legitimasi menegaskan bahwa perusahaan terus berupaya agar operasi mereka sesuai dengan norma dan nilai yang berlaku di masyarakat yang merupakan suatu bentuk kesadaran bagi perusahaan akan tanggung jawab lingkungannya. Belum adanya standar pengungkapan lingkungan memberi kelonggaran bagi perusahaan untuk menggunakan pendekatan simbolik karena kelebihan yang dimiliki seperti hasil penelitian Yin et al. (2019) yang mengatakan bahwa melalui pengungkapan secara simbolik berupa informasi yang cenderung subjektif yang lebih banyak menggunakan narasi bahasa dalam mengungkapkan informasi lingkungannya, sehingga menurut Cormier \& Magnan (2013). semakin tekstual informasi maka semakin menarik publik karena kecenderungan kebiasaan publik lebih suka informasi yang tekstual saat membaca laporan lingkungan akan menambah daya tarik pembaca laporan informasi lingkungan karena lebih mudah dipahami sehingga berdampak pada kinerja perusahaan.

Hasil pengujian menunjukkan bahwa nilai perusahaan dapat memoderasi pengaruh Environmental Information Disclosure (EID) terhadap kinerja keuangan untuk pengungkapan gaya subtantif. Perusahaan dengan pengungkapan lingkungan pendekatan gaya subtantif memberikan kualitas informasi yang aktual dan transparan kepada investor melalui penyajian informasi yang rinci berupa data kuantitaif maupun kualitatif sehubungan dengan pengelolaan lingkungan. Data kuantitatif berupa aspek keuangan menjadi fokus para investor untuk menanamkan sahamnya kepada perusahaan yang secara aktif melakukan 
pengelolaan lingkungan. Kesadaran perusahaan dalam mengungkapkan informasi lingkungan menjadi suatu keharusan sehingga menyebabkan perusahaan memiliki tingkat sensitivitas yang tinggi terhadap masalah lingkungan sebagai bentuk tanggung jawab atas kegiatan operasinya. Kesadaran ini yang akan memberikan daya tarik investor terhadap bentuk tindakan nyata kepedulian perusahaan terhadap lingkungan.

Teori signaling menjelaskan tentang pemberian sinyal positif atau negatif kepada pengguna laporan keuangan. Sinyal positif meningkatkan nilai dan kinerja perusahaan, sedangkan sinyal negatif sebaliknya. Manajemen yang berkomitmen cenderung mengirim sinyal positif untuk meningkatkan keandalan informasi ditunjukkan melalui laporan keberlanjutan atau CSR yang memuat informasi lingkungan untuk memberi sinyal kepada pemangku kepentingan tentang komitmen perusahaan dan kebijakan jangka panjang untuk keberlanjutan manajemen. Hasil penelitian Pratama dkk. (2020) didukung oleh Ernest \& Young (2013) menunjukkan bahwa menciptakan komitmen lingkungan yang baik dapat mempengaruhi setiap harapan perusahaan untuk meningkatkan nilai perusahaan yang bertujuan untuk pemangku kepentingan melalui transparansi pengungkapan informasi lingkungannya yang terdapat dalam laporan keberlanjutan. Sehingga keandalan informasinya dapat dilihat melalui keaktualan data yang cenderung bersifat kuantitatif.

Hasil pengujian menunjukkan bahwa nilai perusahaan tidak dapat memoderasi pengaruh Environmental Information Disclosure (EID) terhadap kinerja keuangan untuk pengungkapan gaya simbolik. Bentuk kesadaran terhadap masalah lingkungan menjadi keputusan perusahaan dalam mengungkapkan informasi lingkungan sehubungan dengan aktivitas operasinya, sehingga perusahaan memiliki kebebasan dalam mengungkapkan bentuk informasi lingkungannya. Menurut Melloni et al. (2017) bahwa pelaku lingkungan yang buruk lebih suka mengungkapkan lebih sedikit data kuantitatif atau tidak mengungkapkannya sama sekali. Informasi deskriptif berupa narasi bahasa yang berlebihan dan publisitas aktivitas pengelolaan lingkungan untuk menarik perhatian publik tanpa dukungan kinerja lingkungan aktual dapat menyebabkan kehilangan kepercayaan pada perusahaan, sehingga investor cenderung mengurangi transaski dengan perusahaan tersebut.

Menurut penelitian Nasution dan Adhariani (2016) bahwa strategi legitimasi dilakukan perusahaan dengan menerbitkan laporan CSR secara sukarela dengan mengikuti nilai-nilai lingkungan dan sosial sebagai bentuk citra perusahaan meskipun belum terbukti melakukan tindakan secara nyata di masyarakat (greenwashing). Hal tersebut merupakan suatu cara untuk memanipulasi persepsi pemangku kepentingan melalui tindakan yang bersifat simbolis, sehingga berakibat pada pelaporan yang bias dan menurunkan kualitas informasi lingkungan. Menurut penelitian Dewi (2019) menunjukkan bahwa pengungkapan laporan keberlanjutan yang terdapat dimensi lingkungan dan sosial belum dianggap sebagai faktor penting bagi investor dalam memilih perusahaan, sehingga tidak dapat meningkatkan jumlah saham yang beredar dan harga saham perusahaan.

\section{PENUTUP}

Berdasarkan hasil penelitian, maka dapat disimpulkan bahwa Environmental Information Disclosure (EID) berpengaruh positif terhadap kinerja keuangan (financial performance) dengan pendekatan gaya subtantif maupun gaya simbolik keduanya sejalan dengan hasil penelitian Yin et al. (2019). Semakin banyak total Environmental Information Disclosure (EID) pendekatan gaya subtantif maka semakin meningkatkan kinerja 
keuangan (financial performance) didukung oleh penelitian Ambec and Lanoie (2008) dan Berrone et al. (2013) melalui pendekatan subtantif. Sedangkan semakin banyak total Environmental Information Disclosure (EID) pendekatan gaya simbolik juga akan semakin meningkatkan kinerja keuangan (financial performance) yang didukung oleh penelitian Cormier \& Magnan (2013). Kemudian untuk perusahaan pendekatan gaya subtantif menunjukkan bahwa nilai perusahaan dapat memoderasi pengaruh Environmental Information Disclosure (EID) terhadap kinerja keuangan (financial performance). Hal ini menunjukkan bahwa investor sebagai pihak eksternal lebih tertarik terhadap perusahaan yang melaporkan informasi lingkungan secara aktual berupa data kuantitatif sehubungan dengan pengelolaan lingkungannya yang sejalan dengan hasil penelitian Pratama dkk. (2020) dan Ernest \& Young (2013). Sedangkan, untuk perusahaan pendekatan gaya simbolik dalam penelitian ini menunjukkan bahwa nilai perusahaan tidak dapat memoderasi pengaruh Environmental Information Disclosure (EID) terhadap kinerja keuangan (financial performance), hal itu sesuai penelitian Nasution dan Adhariani (2016) menunjukkan bahwa praktik CSR yang memuat informasi lingkungan yang dilakukan secara greenwashing, menyebabkan investor kurang tertarik untuk menginvestasikan modal ke perusahaan tersebut.

Keterbatasan dalam penelitian ini yaitu pengklasifikasian gaya pengungkapan melalui selisih item informasi objektif dan informasi subjektif lebih komplek sehingga membutuhkan waktu lama dalam menganalisis satu per satu item pengungkapan. Pemilihan nilai perusahaan sebagai variabel moderasi sehubungan dengan pengungkapan lingkungan masih belum ada.

Penelitian selanjutnya disarankan untuk melakukan klasifikasi gaya pengungkapan menggunakan metode lain seperti penerapan beberapa indeks pengungkapan selain selisih item objektif dan subjektif. Pemilihan variabel moderasi disesuaikan dengan variabel-variabel sehubungan dengan pengungkapan lingkungan.

\section{REFERENCES:}

Al-Tuwaijir, S. A., Christensen, T. E., \& Hughes, K. E. 2004. The relations among environmental disclosure, environmental performance, and economic performance: A simultaneous equations approach. Accounting, Organizations and Society, 29(5-6), 447-471. https://doi.org/10.1016/S0361-3682(03)00032-1

Ambec, S., \& Lanoie, P. 2008. Does It Pay to Be Green? A Systematic Overview. Academy of Management Perspectives, 45-62.

Badan Pusat Statistik. Statistik Lingkungan Hidup Indonesia (2018).

Berrone, P., Fosfuri, A., Gelabert, L., \& R., G.-M. L. 2013. Necessity as The Mother of 'Green' Inventions: Institutional Pressures and Environmental Innovations Pascual. Strategic Management Journal, 34, 891-909. https://doi.org/10.1002/smj

Chen, L., Tang, O., \& Feldmann, A. 2015. Applying GRI reports for the investigation of environmental management practices and company performance in Sweden, China and India. Journal of Cleaner Production, 98, 36-46. https://doi.org/10.1016/j.jclepro.2014.02.001

Clarkson, P. M., Fang, X., Li, Y., \& Richardson, G. 2013. The relevance of environmental disclosures: Are such disclosures incrementally informative? Journal of Accounting and Public Policy, 32(5), 410-431. https://doi.org/10.1016/j.jaccpubpol.2013.06.008

Cormier, D., \& Magnan, M. 2013. The Economic Relevance of Environmental Disclosure and its Impact on Corporate Legitimacy: An Empirical Investigation. Business Strategy and the Environment, 24(6), 431-450. https://doi.org/10.1002/bse.1829 
Daat, S. C., \& Pangayow, B. J. C. 2019. Pengaruh Environmental Performance pada Economic Performance dengan Environmental Disclosure sebagail Pemediasi (Studi Empiris pada Perusahaan Manufaktur dan Pertambangan yang Terdaftar di Bursa Efek Indonesia). Jurnal Akuntansi Dan Keuangan Daerah, 14(1), 5468. https://doi.org/10.1017/CBO9781107415324.004

David, H., \& Milne, M. J. 1996. Some determinants of socialand environmental disclosuresin New Zealand companies. Accounting, Auditing \& Accountability Journal, 9(1), 77-108.

Davies, M., Doris, M., Brennan, \& Niamh. 2007. Discretionary disclosure strategies in corporate narratives: incremental information or impression management? Authors(s). Journal of Accounting Literature, 26, 116195. https://doi.org/10.1680/geot.2008.T.003

Dewi, S. 2017. Pengaruh Ukuran Perusahaan dan Profitabilitas terhadap Pengungkapan Sustainability Report serta Dampaknya kepada Nilai Perusahaan. Jurnal Akuntansi Dan Bisnis, 7(3), 109-120.

Du, X. 2015. How the Market Values Greenwashing? Evidence from China. Journal of Business Ethics, 128(3), 547-574. https://doi.org/10.1007/s10551-014-2122-y

Ernest, \& Young Global Limit. 2013. Value of sustainability reporting. 1-32. Retrieved from http://www.ey.com/Publication/vwLUAssets/EY_-_Value_of_sustainability_reporting/\$FILE/EY-Value-ofSustainability-Reporting.pdf

Fahmi, I. 2011. Analisis Laporan Keuangan. Lampulo: ALFABETA.

Freeman, R. E., \& Dmytriyev, S. 2017. Corporate Social Responsibility and Stakeholder Theory : Learning From Each Other. Symphonya, Emergging Issues in Manajemen, 2(1), 7-15.

Ghisetti, C., \& Rennings, K. 2014. Environmental innovations and profitability: how does it pay to be green? An empirical analysis on the German innovation survey. Journal of Cleaner Production, 75(13), 106-117. https://doi.org/10.1016/j.jclepro.2014.03.097

Ikhsan, A. 2009. Akuntansi Manajemen Lingkungan (Edisi Pert). Yogyakarta: Graha Ilmu.

Jones, S., Frost, G., Loftus, J., \& Laan, S. 2007. An Empirical Examination of the Market Returns and Financial Performance of Entities Engaged in Sustainability Reporting. Australian Accounting Review, 17(41), 78-87. https://doi.org/10.1111/j.1835-2561.2007.tb00456.x

Liu, W., Wei, Q., Huang, S. Q., \& Tsai, S. B. 2017. Doing good again? A multilevel institutional perspective on corporate environmental responsibility and philanthropic strategy. International Journal of Environmental Research and Public Health, 14(10), 1-15. https://doi.org/10.3390/ijerph14101283

Ma, Y., Hou, G., \& Xin, B. 2017. Green process innovation and innovation benefit: The mediating effect of firm image. Sustainability (Switzerland), 9(10), 22-24. https://doi.org/10.3390/su9101778

Mardiana, I. A., \& Wuryani, E. 2019. Pengaruh Kinerja Lingkungan Terhadap Nilai Perusahaan dengan Profitabilitas sebagai Variabel Pemoderasi. Akuntansi Unesa, 8(1).

Melloni, G., Caglio, A., \& Perego, P. 2017. Saying more with less? Disclosure conciseness, completeness and balance in Integrated Reports. Journal of Accounting and Public Policy, 36(3), 220-238. https://doi.org/10.1016/j.jaccpubpol.2017.03.001

Montabon, F., Sroufe, R., \& Narasimhan, R. 2007. An examination of corporate reporting, environmental management practices and firm performance. Journal of Operations Management, 25(5), 998-1014. https://doi.org/10.1016/j.jom.2006.10.003

Nasution, R. M., \& Adhariani, D. 2016. Simbolis atau Substantif? Analisis Praktik Pelaporan CSR dan Kualitas Pengungkapan. Akuntansi Dan Keuangan Indonesia, 13(1), 23-51.

Nor, N., Aishah, N., Bahari, S., Adnan, N. A., Qamarul, M., Sheh, A., \& Mohd, I. 2016. The Effects of Environmental Disclosure on Financial Performance in Malaysia. Procedia Economics and Finance, 35(October 2015), 117126. https://doi.org/10.1016/S2212-5671(16)00016-2

Plumlee, M., Brown, D., Hayes, R. M., \& Marshall, R. S. 2015. Voluntary environmental disclosure quality and firm value: Further evidence. Journal of Accounting and Public Policy, 34(4), 336-361. https://doi.org/10.1016/j.jaccpubpol.2015.04.004

Pratama, M. F. G. P., Purnamawati, I., \& Sayekti, Y. 2020. Analisis Pengaruh Kinerja Lingkungan dan Pengungkapan Sustainability Reporting Terhadap Nilai Perusahaan. Jurnal Akuntansi Universitas Jember, 
17(2), 110. https://doi.org/10.19184/jauj.v17i2.12517

Rahardjo, B. 2007. Keuangan dan Akuntansi untuk Manajer Non Keuangan (Pertama). Yogyakarta: Graha IImu.

Ramus, C. A., \& Montiel, I. 2005. When are corporate environmental policies a form of greenwashing? Business and Society, 44(4), 377-414. https://doi.org/10.1177/0007650305278120

Sari, W. H., Agustin, H., \& Mulyani, E. 2019. Pengaruh Good Corporate Governance dan Kinerja Lingkungan terhadap Pengungkapan Lingkungan (Studi Empiris pada Perusahaan Manufaktur yang Terdaftar di Bursa Efek Indonesia Tahun 2013-2017). Eksplorasi Akuntansi, 1(1), 18-34.

Sawitri, A. P., \& Setiawan, N. 2017. Analisis Pengaruh Pengungkapan Sustainability Report, Kinerja Keuangan, Kinerja Lingkungan Terhadap Nilai Perusahaan. Journal of Business \& Banking, 7(2), 1-8. https://doi.org/10.14414/jbb.v7i2.1397

Suryati, A. K., Gama, A. W. S., \& Astiti, N. P. Y. 2019. Pengaruh Corporate Social Responsibility terhadap Nilai Perusahaan dengan Profitabilitas sebagai Variabel Moderasi (Studi Empirirs Pada Perusahaan Pertambangan yang Terdaftar di Bursa Efek Indonesia Periode 2014 - 2016). Manajemen, 17(2), 111-121.

Undang-Undang 32 Tahun 2009 tentang Perlindungan Pengelolaan Lingkungan Hidup. (2016). Otoritas Jasa Keuangan. Retrieved March 27, 2020, from Otoritas Jasa Keuangan website: https://www.ojk.go.id/sustainable-finance/id/peraturan/undang-undang/Pages/Undang-Undang-No.32Tahun-2009-mengenai-Perlindungan-dan-Pengelolaan-Lingkungan-Hidup.aspx

Wang, X., Sun, C., Wang, S., Zhang, Z., \& Zou, W. 2018. Going Green or going away? A spatial empirical examination of the relationship between environmental regulations, biased technological progress, and green total factor productivity. International Journal of Environmental Research and Public Health, 15(9), 1-23. https://doi.org/10.3390/ijerph15091917

Wijaya, A. L., \& Pancawati, E. L. 2019. Pengaruh Pengungkapan Corporate Social Responsibility ( CSR ) dan Profitabilitas terhadap Nilai Perusahaan dengan Struktur Modal sebagai Variabel Pemoderasi (Studi Pada Perusahaan Food and Beverage Tahun 2013-2017). Inventory: Jurnal Akuntansi, 3(2), 131-140.

Yin, H., Li, M., Ma, Y., \& Zhang, Q. 2019. The Relationship between Environmental Information Disclosure and Profitability : A Comparison between Di ff erent Disclosure Styles. International Journal of Environmental Research and Public Health, 16, 1-14. https://doi.org/10.3390/ijerph16091556 
